\title{
FISIOLOGIA E FISIOPATOLOGIA DO SISTEMA LINFORETICULAR
}

\author{
A. Oliveira Lima *
}

Quando um agente invasor, capaz de reprodução e multiplicação nos tecidos, penetra na intimidade do sistema linforeticular (SLR), as seguintes alterações poderão ocorrer na capacidade reacional do hospedeiro: 1) tornar-se imune e mais resistente ao agente invasor; 2) ficar hipersensivel a esse agente, ou a seus produtos; 3 ) adquirir um estado específico de tolerância ou de paralisia imunológica; 4) evoluir para um estado de deficiência imunológica, tornando-se incapaz de combater a agressão. Todos esses estados dependem da interação entre o parasita e o hospedeiro, envolvendo na sua intimidade participação de toças as células do sistema linforeticular.

\section{O AGENTE INVASOR}

De parte do parasita (virus, bactéria, protozoário, fungo, etc.) há inúmeros fatores a interferir, em maior ou menor grau, na capacidade reacional do SLR; presença de cápsulas ou de flagelos, natureza dos componentes da parede e da membrana celular, presença de exo ou de endotoxinas, atividade citopática, parasitismo intra ou extra-celular, moơulação antigênica durante o ciclo evolutivo do parasita, intensidade do parasitismo, vias de penetração etc.

\section{O SISTEMA LINFORETICULAR}

A figura 1 nos dá uma visão esquemática dos componentes do sistema linforeticular.

O SLR poderá, portanto, ser estudado em três niveis diferentes: 1) dos órgãos produtores de células indiferenciadas primitivas (célula reticular primitiva) de onde provêm as células linfoides e os macrófagos; 2) dos órgãos linfoides centrais (ou primários), como o timo e bursa de Fabricius, locais de ulterior maturação funcional e de intensa divisāo das células linfoides; 3) do sistema linfoide periférico (ou secundário), como os linfonodos, o baço, onde as células linfoides reagem ao agente invasor. O SLR se compõe, essencialmente, de três tipos de células: os macrófagos que pertencem ao sistema retículoendotelial e os linfócitos $\mathbf{T}$ e B, pertencentes ao tecido linfoide.

\section{AS CÉLULAS PRECURSORAS DO SISTEMA LINFORETICULAR}

As células precursoras do SLR provêm, na vida fetal, de células primitivas do saco vitelino e que migram para o fígado fetal e a medula óssea. A medula, na vida extrauterina, representa um compartimento 


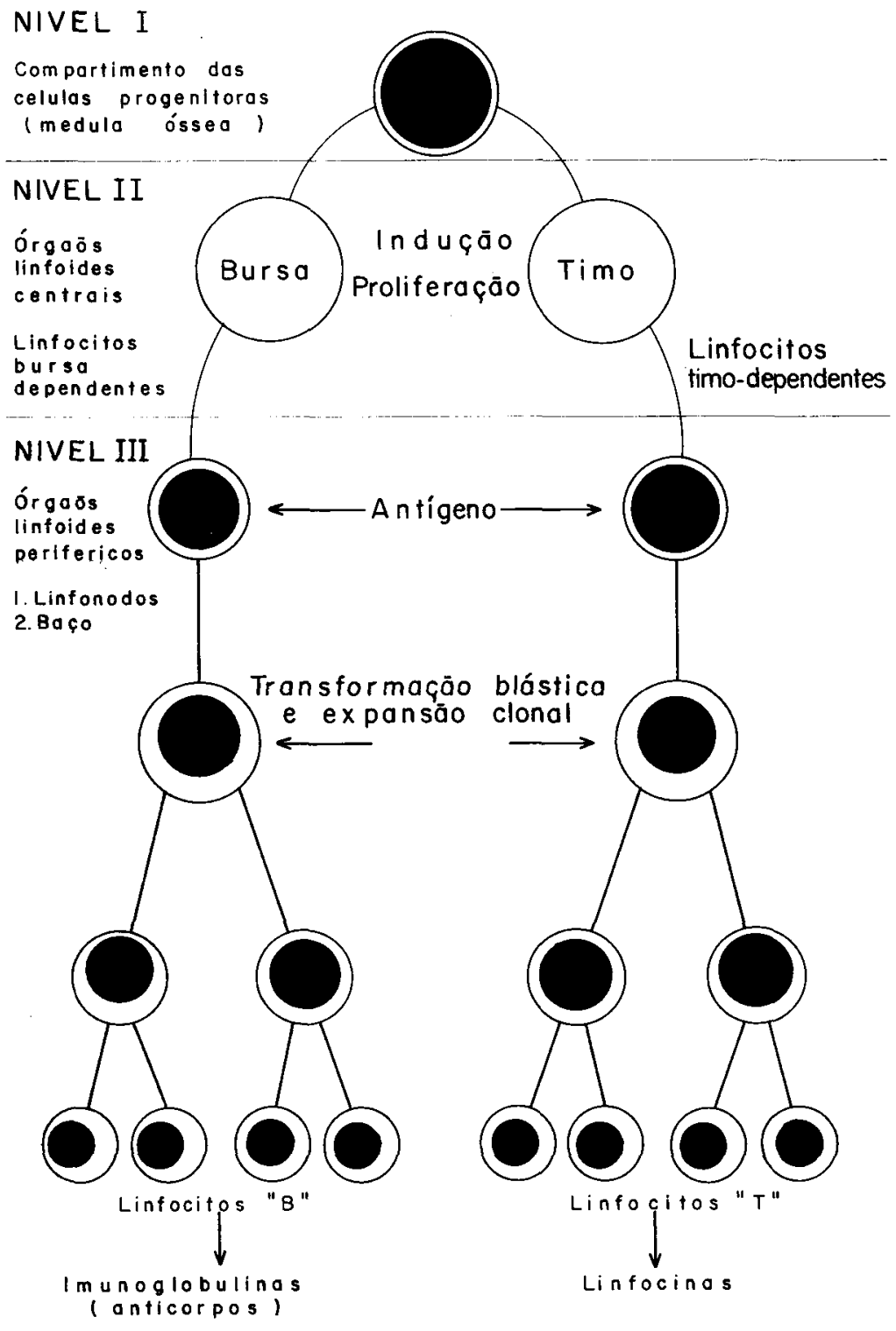

Fig-l Representacio esquemática dos três compartímentos do sistema linforeticulor. 
importante do SLR. As células reticulares primitivas podem circular pelo sangue $\mathrm{e}$ linfa, mas nāo reagem ao antígeno, comportando-se como células imunologicamente incompetentes no sentido convencional. As células primitivas que migram para o timo sofrem extensa diferenciação e se transformam em timócitos, que também se diferenciam antes de migrar para os órgãos linfoides periféricos (linfonodos, baço), o sangue e a linfa, onde passam a ser chamados de linfócitos $T$, ou timo-dependentes. As células primitivas que não migram para o timo também se diferenciam e se multiplicam, passano a ser chamadas de linfócitos $B$, bursa-dependentes ou timoindependentes. Nas aves essa diferenciação ocorre na bursa de Fabricius, tecido linfoide apenso à cloaca; nos mamiferos, provavelmente no tecido linfoide do aparelho digestivo, nos linfonodos, no baço. Os linfócitos T e B vão habitar os órgãos linfoides periféricos, o sangue e a linfa. Também os macrófagos se originam da célula reticular primitiva da medula óssea.

\section{OS ÓRGÃOS LINFOIDES CENTRAIS}

Os órgãos linfoides são hoje classificados em dois grupos: 1) centrais, ou primários; 2) periféricos, ou secundários. O timo e bursa de Fabricius são os órgãos centrais; os linfonodos, o baço, as placas de Payer, os periféricos. Para alguns autores o tecido linfoide do aparelho digestivo (amígdalas, placas de Payer, apêndice) teria função de órgāo central, equivalente à da bursa.

Três são as características principais dos órgãos linfoides centrais: 1) não formam anticorpo em condições normais; 2) a intensidade da linfopoiese de suas células não depende da estimulação antigênica; 3 ) encerram formação de células epiteliais. Nos órgãos centrais as células reticulares primitivas sofrem amadurecimento e diferenciação em células imunocompetentes. O timo se divide em lóbulos com medula e córtex, contendo células reticulares, linfócitos, macrófagos e células epiteliais. Estas ültimas predominam na medula, formando os corpúsculos de Hassal. Em condiçōes normais o timo não contém folículos linfoides, nem plasmócitos.

A bursa de Fabricius, peculiar às aves, é uma estrutura linfoepitelial justaposta à cloaca, também com porção medular e cortical.

Os linfócitos $\mathrm{T}$ procedem de células que se diferenciaram no timo. Os linfócitos B provêm de células que se diferenciaram na bursa ou em tecido linfoide equivalente, nos mamíferos. Dos órgãos linfoides centrais esses linfócitos, já imunocompetentes, passam para a circulação e para os órgãos linfoides periféricos. Há evidências de que as células epiteliais do timo elaboram um fator hormonal capaz de interferir na maturação dos linfócitos.

\section{OS ÓRGĀOS LINFOIDES PERIFÉRICOS}

Os linfonodos e o baço são os principais órgãos linfoides periféricos, para onde migram os linfócitos T e B. Ali também estão as células do sistema retículo-endotelial, os macrófagos.

Linfonodos. - Nos linfonodos podem ser delimitadas três zonas: 1) cortical, com os folículos linfoides;: 2) sub-cortical, difusa; 3) medular, com os seios e cordões medulares. A linfa penetra nos linfonodos pelos linfáticos aferentes, segue pelos seios circulares, seios medulares e através da córtex, escoando-se pelos linfáticos eferentes. Os seios linfáticos sāo revestidos por células com características biológicas dos macrófagos. Há duas categorias de folículos na córtex dos linfonodos: 1) primários, não possuindo centros germinativos; 2) secundários, com centros germinativos. Estes últimos são em células pironinófilas, restos de linfócitos, macrófagos e estão envolvidos por um manto de pequenos linfócitos. Na ausência de estimulação antigênica predominam os folículos primários. Quando adequadamente estimulados, estes se transformam em folículos secundários, no centro dos quais se formam os anticorpos. O tecido que fica entre os folículos linfoides e entre os folículos e a medula é o chamado tecido subcortical difuso (ou zona para-cortical) dos linfonodos. Os antigenos que inciuzem hipersensibilidade retardada (virus, bacterias, fungos patogênicos etc.) estimulam e proliferam de preferência as células imunocompetentes dessa zona paracortical, onde predominam os linfócitos $\mathrm{T}$ e, por isso, também chamada zona timo-dependente. Possui vênulas póscapilares revestidas por endotélio cuboide 

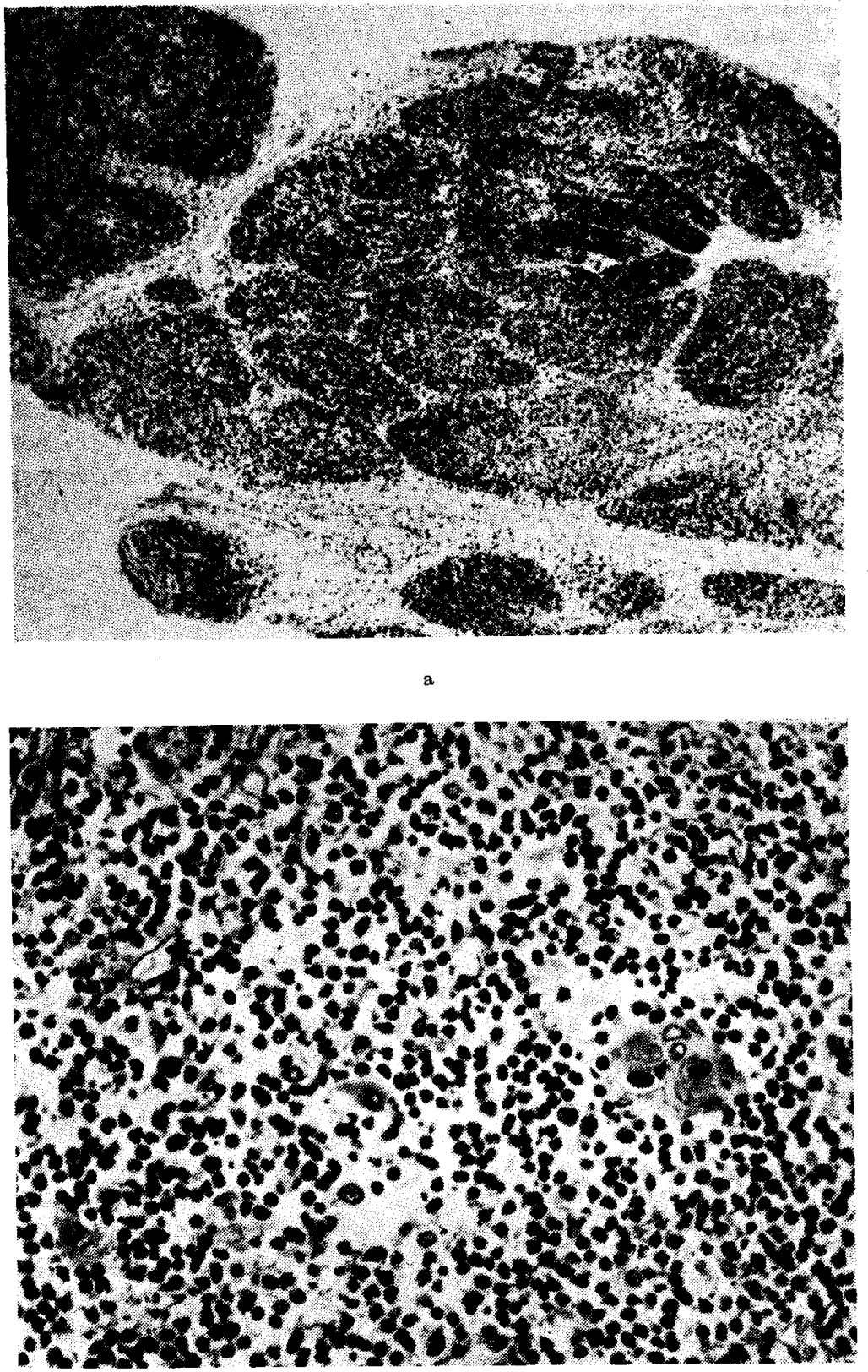

b

Fig. 2 (a) Timo humano de recem-nascido. (b) Grande aumento para mostrar os corpúsculos de Hassal na reglāo medular. 


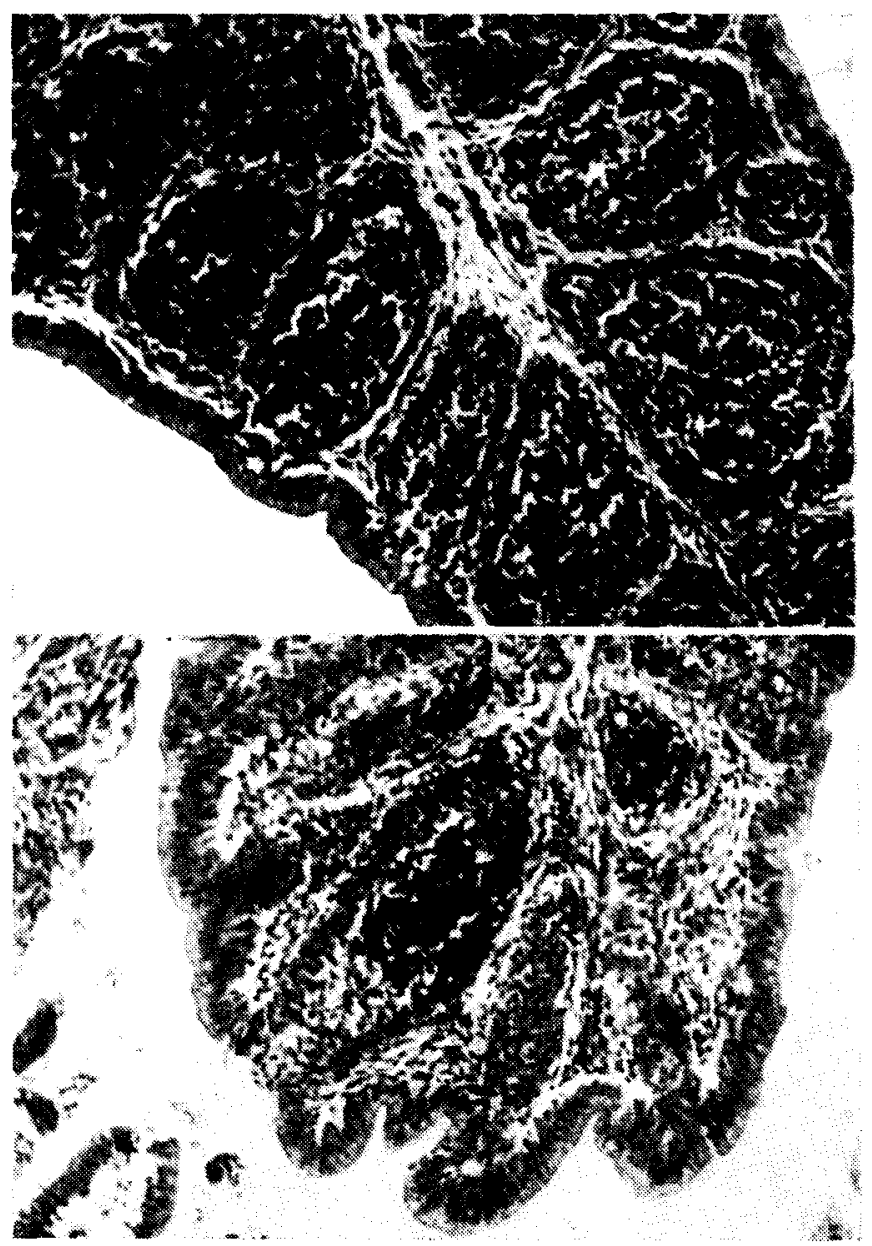

F:s. 3 Bursa de Frbricius. Órgão linfótde central das aves, ao lado do timo.

alto, por onde atravessam os linfócitos recirculadores. Zona pobre em macrófagos e neutrófilos.

A zona medular ponetra nos linfonodos formando interdigitações entre os seios. Na ausência də estímulo antigênico apresenta estrutura pouco proeminente, mas a partir de quarto dia de estimulação de respostas imediata, acusa infiltração por células pironinófilas, proliferação de células plasmáticas, linfócitos, macrófagos. As células plasmáticas maduras tendem a permanecer na medula oncie se formam, enquanto os linfócitos, em geral, migram pelos linfáticos eferentes. Os seios medu- laros também recobertos por endotélio (macrófagos) são os maiores filtros dos linfonodos.

Baço. - O baço difere dos linfonodos pelas seguintes caracteristicas: 1) exerce funçōas não linfoides, como eritropoiese, mielopoiese; 2) recebe material através do sangue, não tendo porta de entrada correspondente aos linfáticos aferentes; 3) não tom estrutura semelnante à dos seios meciulares capaz de reter material antigênico, mas apenas zona marginal, com mecanismo funcional diferente. No baço deve-se considerar a polpa branca, a polpa 


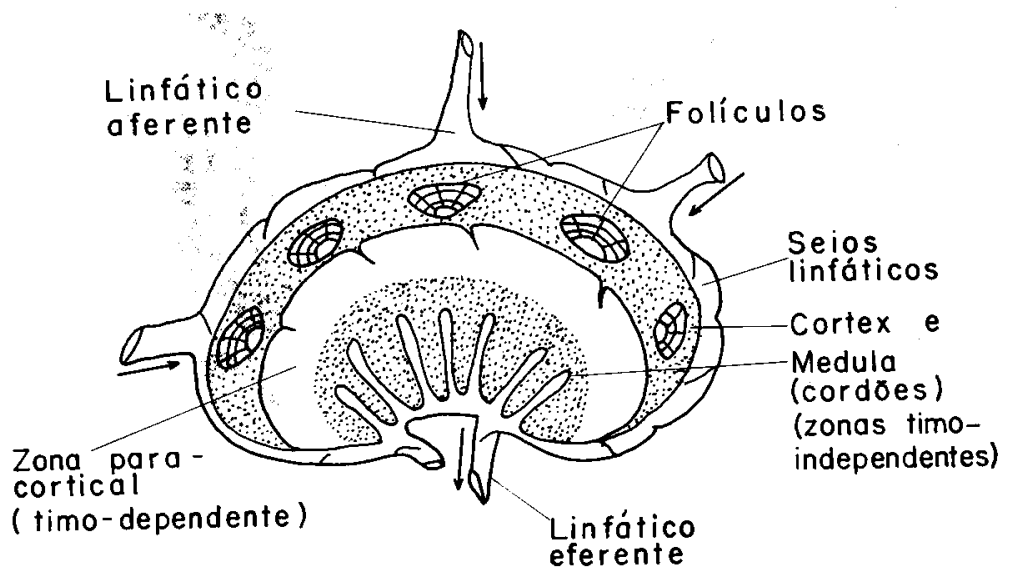

Fig. 4 Representação esquemática do linfonodo mostrando as áreas de dependência: timo-dependente e timo-independente (ou bursa-dependente).

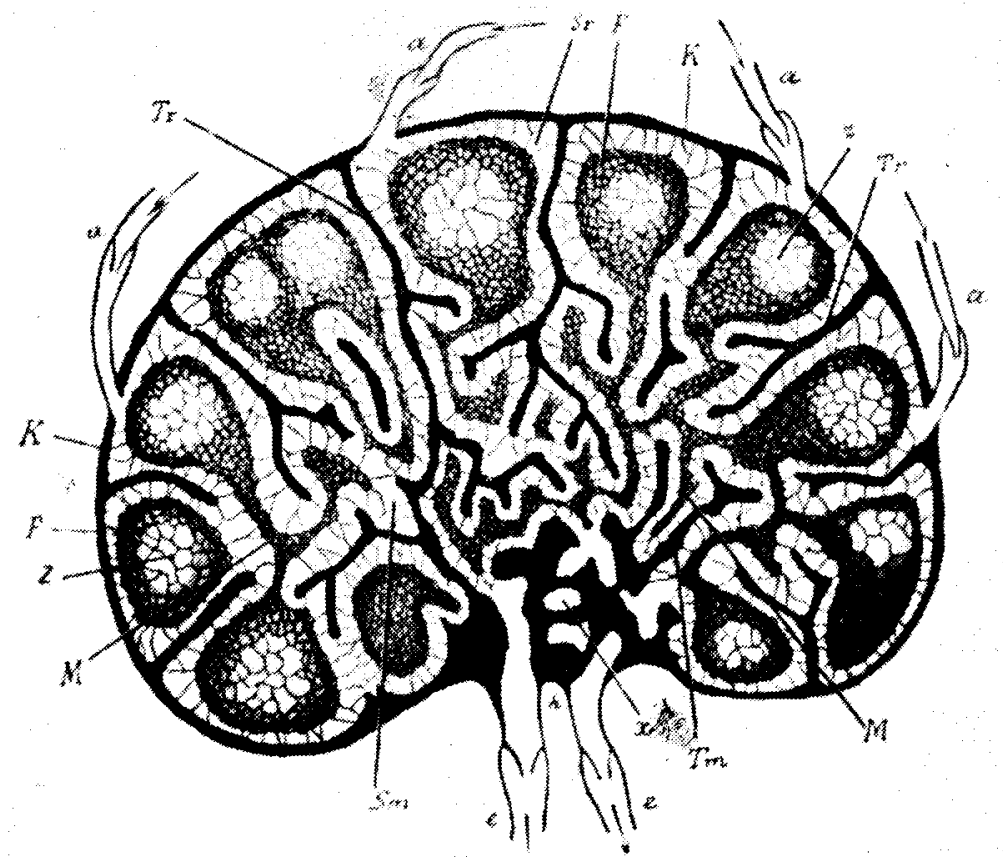

Fig. 5 Linfonodo mostrando a distribulçăo dos linfáticos, os cordóes medulares e os folículos corticais. 
vermelha $e$, entre ambas, a zona marginal, que envolve o seio marginal.

A polpa branca contém tecido linfoide difuso $\mathrm{e}$ os foliculos linfoides. O tecido difuso que corresponde ao tecido cortical e paracortical dos linfonodos, é o chamado manto linfocitico peri-arteriolar, que envolve a arteriola central, zona timo-depenciente. Os folículos secundários são đe aspecto semelhante ao dos linfonodos. A zona marginal consiste de tecido reticular frouxo, com as células reticulares emitindo longas ramificações, linfócitos, macrófagos e células pironinófilas. Acha-se em comunicação com a polpa vermelha. Quando sob estimulação antigênica apresenta massas de plasmócitos em diferentes estádios de maturação.

\section{AS CÉLULAS DO SISTEMA LINFORETICULAR}

Macrófagos. - O termo macrófago no seu sentido mais amplo, engloba as células mononucleares dotadas da capacidde de fagocitar material particulado, de pinocitar substâncias solúveis e de acumular corantes vitais. Dentro desse critério são considerados como macrófagos os plasmatócitos, as células de Kupfer, os monócitos de sangue circulante (macrófagos imaturos), os histiócitos, as células adventícias, as células ragiocrinas, as células septais do pulmão, as células da microglia. Os macrófagos se encontram em todos os órgãos constituincio, no conjunto, o sistema retículo endotelial, como se vê no quadro seguinte.

Sistema Retículo Endotelial

\begin{tabular}{|c|c|c|c|c|c|c|}
\hline $\begin{array}{l}\text { Tecido linfoide } \\
\text { periférico (linfo- } \\
\text { nodos, baço) }\end{array}$ & Timo & $\begin{array}{l}\text { Fígado, } \\
\text { medula dos } \\
\text { ossos }\end{array}$ & $\begin{array}{c}\text { Cavidades } \\
\text { serosas }\end{array}$ & Sangue & $\begin{array}{l}\text { Sistema } \\
\text { nervoso } \\
\text { central }\end{array}$ & $\begin{array}{l}\text { Tecido } \\
\text { conjun- } \\
\text { tivo }\end{array}$ \\
\hline $\begin{array}{l}\text { Macrófagos dos } \\
\text { seios }\end{array}$ & $\begin{array}{l}\text { Histióci- } \\
\text { tos peri- } \\
\text { vascula- } \\
\text { res }\end{array}$ & $\begin{array}{l}\text { Macrófa- } \\
\text { gos dos } \\
\text { seios lin- } \\
\text { fáticos }\end{array}$ & $\begin{array}{l}\text { Macró- } \\
\text { fagos }\end{array}$ & $\begin{array}{l}\text { Monóci- } \\
\text { tos }\end{array}$ & $\begin{array}{l}\text { Micro- } \\
\text { glia }\end{array}$ & $\begin{array}{l}\text { Histió- } \\
\text { citos }\end{array}$ \\
\hline $\begin{array}{l}\text { Células dendriti- } \\
\text { cas dos folículos }\end{array}$ & & & & & & \\
\hline $\begin{array}{l}\text { Macrófagos "tin- } \\
\text { gible bodies" dos } \\
\text { centros germina- } \\
\text { tivos }\end{array}$ & $\begin{array}{l}\text { Macrófa- } \\
\text { gos "tin- } \\
\text { gible bo- } \\
\text { dies" }\end{array}$ & & & & & \\
\hline
\end{tabular}

Os monócitos do sangue são considerados como forma jovem, imatura, dos macrófagos, de passagem para os tecidos. Exercem funçôes dos macrófagos embora em menor intensidade. A estrutura e morfologia dos macrófagos varia, de certo modo, na dependência da sua localização nos tecidos e da sua atividade. Cerca de $30 \%$ caas células do fígado são constituídas por células de Kupfer, que revestem os sinusoides hepáticos. Nos tecidos linfoides existem três tipos de macrófagos: 1) macrófagos dendríticos dos folículos germináticos; 2) macrófagos "tingible bodies", dos centros germinativos dos folículos secundários da córtex dos linfonodos e da polpa branca đo baço; 3) macrófagos clássicos, que revestem os seios dos linfonodos e do baço.

Os monócitos do sangue provêm, dominantemente, dos promonócitos da medula 


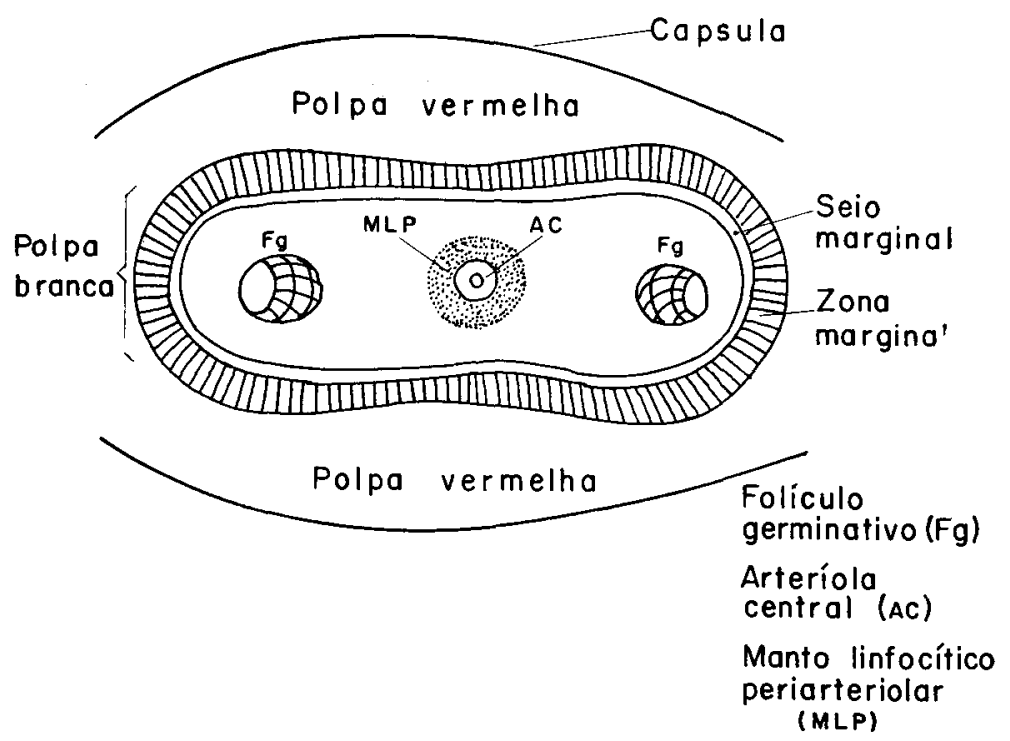

Fig. 6 Representaçâo esquemática do baço mostrando as parçôes da polpa branca de - maior interesse" nas reaçóes imunológicas.

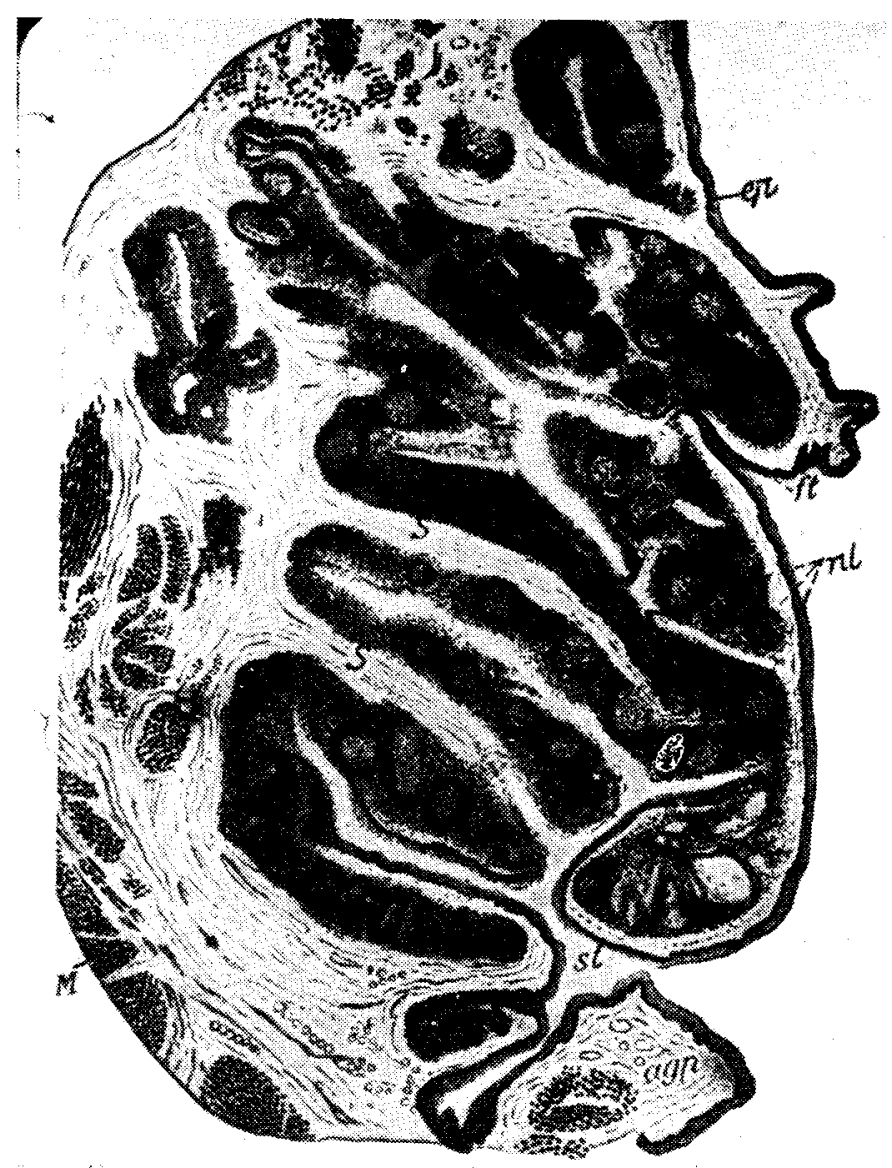

Fig. 7 Amigdala palatina. Para alguns autores poderia funcionar como órgão linfóide central. 
óssea, células dotadas de grande atividade mitótica.

Funções dos macrófagos. - Dentre as principais funções dos macrófagos figuram as seguintes: 1) fagocitose e pinocitose de substâncias estranhas aos tecidos; 2) fagocitose de células envelhecidas ou alteradas por mecanismos diversos; 3) fagocitose de substâncias que se formam no metabolismo celular; 4) controle do metabolismo da hemoglobina, do ferro, dos lipides, do osso; 5) reparação de tecidos nos processos inflamatórios; 6) captação, processamento e armazenamento de antígenos; 7) destruição de complexos antigeno-anticorpo; 8) elaboração de interferon e de certos componentes do complemento.

Fagocitose e pinocitose. - Os autores costumam esiudar a fagocitose $\epsilon \mathrm{m}$ duas etapas: 1) da aderência àa partícula ao fagocito; 2) da incorporação ao fagocito da partícula aderida. Seria útil, no entanto, subdividir essas duas etapas nas seguintes: quimiotaxia, opsonização, imunoaderéncia, endocitose, formação de vacúolos fagociticos (fagosomas), degranulação dos lisosomas, formação de fagolisosomas, destruição ou eliminação (exocitose) da substância ingerida.

A quimiotaxia consiste na migração unidirecional do fagocito orientado por um gradiente da substîncia ativa. Dentre os agentes quimiotáticos ficuram certos fragmentos do complemento (C3a, C5a), o complexo macromolecular do complemento C567, agentes elaborados por bactérias, peptídeos cationicos dos lisosomas, substâncias elaboradas pelos linfócitos e neutrófilos, etc. A opsonização e imunoaderência são etapas que se seguem à quimiotaxia. Funcionam como agentes opsônicos e imunoaderentes as imunoglobulinas (IgG, IgM) e o complemento (C3, C4). As imunoglobulinas funcionam íixando-se às membranas dos macrófagos pela porção Fc. A aderência das partículas à superîicie dos macrófagos precede à fagocitose, isto é, à interiorização da membrana do fagócito. Essa aderência poderá ocorrer por mecanismos diversos: 1) pelo encontro ao acaso do macrófago com a partícula numa superfície apropriada; 2) pela atração eletrostática; 3 ) pela aderência ảa particula, em geral um agente estruturado (célula, bactéria) ao macrófago através de anticorpos ou do complemento de complexos antigeno-anticorpo. Nos primeiros casos a fagocitose é chamada não-imunológica; no último, imunológica. Depois de aderida a partícula à superfície do macrófago, correm vários fenômenos que podem ser assim resumidos: 1) interiorização da partícula por invaginação e fusão da membrana plasmática, formando o vacúolo fagocítico (fagosoma) desprovido de enzimas; 2) movimentação dessas vesículas para o centro da célula, onde se fundem com os lisosomas do citoplasma, dos quais recebem as enzimas e se transformam em estrutura digestiva; 3) destruição da particula ingerida ou sua eliminação para fora da célula (exocitose) .

o mecanismo da pinocitose é basicamente semelhante ao cia fagocitose, do qual se difere pelo fato de incorporar substâncias solúveis e pelo fato de as vesículas resultantes serem menores.

Mobilização dos macrófagos. - Quando o organismo necessita de maior número de macrófagos, no advento de agressão em determinado tecido, ocorrerão os seguintes fenômenos: 1) estimulação e proliferação das células progenitoras da medula óssea e sua transformação em promonócitos; 2) entracia dos promonócitos da circulação medular e sua transformação em monócitos; 3) penetração dos monócitos nos tecidos comprometidos e sua transformação em macrófagos; 4) mobilização dos macrófagos de depósitos próximos ao tecido lesado. Os macrófagos podem se organizar em granulomas nos tecidos, quando as células estimuladas pelas linfocinas, aderem entre si pelas projeções digitais e aciquirem o aspecto de cálulas epitelioides. Os estímulos (bactérias, etc.) que atuam sobre os macrófagos podem transformá los em "macrófagos ativados" que apresentam entre outras, as seguintes caracteristicas: maior atividade metabólica, maior número de lisosomas, maior teor de enzimas, maior capacidade de fagocitose, maior mobilidade. Dentre os estímulos de maior importância nessa ativação cios macrófagos, figuram os lipides e endotoxinas bacterianos ( $M$. tuberculosis, M. leprae, L. monocytogenes, Brucella, Salmonella, C. parvum, ets.).

Interação do antígeno com os macrófagos. - Dois tipos de macrófagos dos te- 

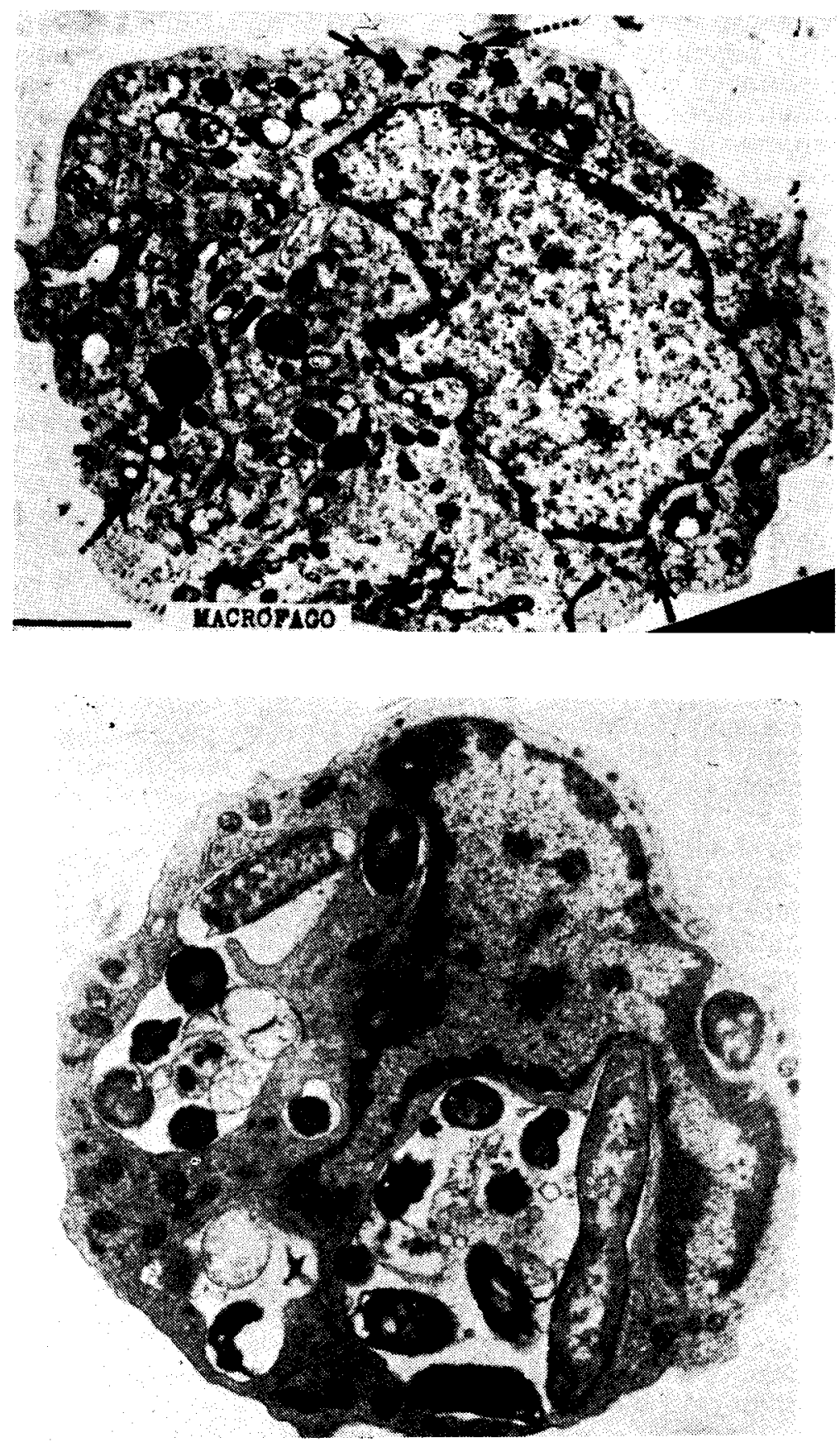

Fig. 8 Macrófagos, contendo material fagocitado em fagolisosomas. 


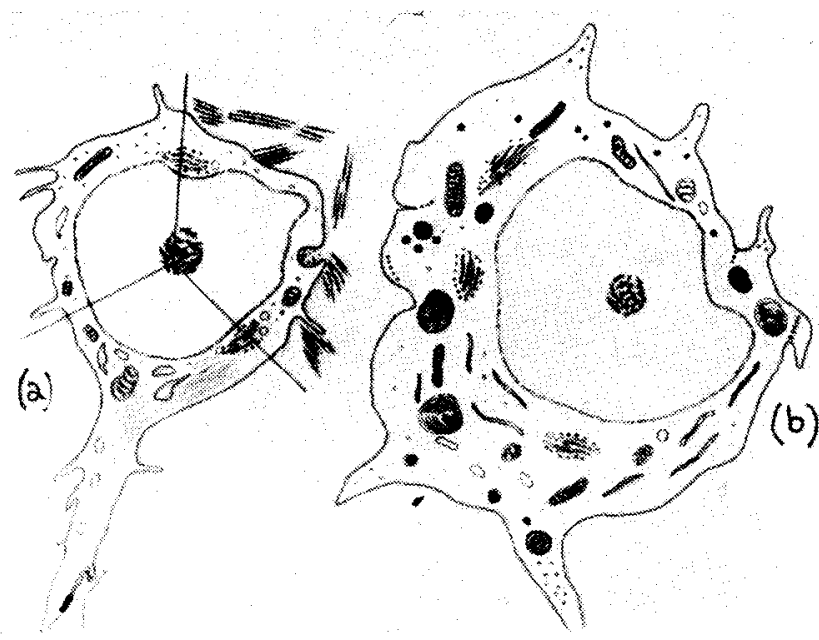

Fig. 9 Macrófagos: (a) deùdrítico; (b) fagccítico, clássico.

cidos têm sido bem estudados na captação de antigenos e de complexos antigeno-anticorpo. Um deles predomina na cavidade peritoneal e nos seios dos órgãos linfoides periféricos. O outro, o que retem o antigeno na sua membrana plasmática, o chamado macrófago dendrítico, predomina nos folículos linfoides. Há duas maneiras conhecidas de localização do antígeno nos nódulos linfoides: 1) fixando-se à porção Fab livre do anticorpo citofílico aderido à superfície do macrófago pela porção Fc; 2) fixancio-se através do complemento do complexo antígeno-anticorpo. O antígeno pode ser fagocitado e totalmente degradado pelos macrófagos, ou ser neles retida uma pequena porção dotada de atividade imunológica.- Os macrófagos embora não sintetizem anticorpos, interferem de vários modos na sua formaçāo: 1) competindo com os linfócitos na captação do antígeno; 2) processando o antígeno e aumentando sua potencialidade imunogênica; 3 ) elaborando RNA capaz de conferir a linfócitos normais a capacidade de formar anticorpos específicos para o antígeno fagocitado.

Relaçōes anatômicas entre macrófagos e linfócitos. - Os macrófagos dos seios e cordões medulares dos linfonodos se acham em contato estreito com as células linfoides. O papel auxiliar dos macrófagos na prođução de anticorpos se demonstra entre outros métodos: 1) pela presença de linfó- citos em volta dos macrófagos, formando rosetas; 2) pela transformação blastoide dos linfócitos mais próximos aos macrófagos; 3) pela formação de pontes citoplasmática entre macrófagos e plasmócitos ou linfócitos.

Linfócitos. - Há pelo menos duas classes distintas de linfócitos periféricos, tendo em mente suas propriedades biológicas: $T$ e B. Os linfócitos $T$ provêm de célula precursora da meciula óssea que migra para o timo onde se diferencia em timócito. o timócito perde alguns dos seus antígenos da membrana e migra para os órgãos linfoides periféricos onde recebe os nomes de linfócitos $T$, linfócitos timo-dependentes. Os linfócitos B também têm sua origem numa célula precursora da medula e migram para a periferia. Nas aves essa diferenciação se faz na bursa de Fabricius; nos mamíferos, em algum tecido "bursaequivalente" ou nos próprios órgãos linfoides periféricos. Esse tipo de linfócito que se diferencia sem passar pelo timo é também chamado "timo-independente", "bursadependente". Os linfócitos T e B săo morfologicamente indistinguiveis. Ambos são encontrados nos tecidos linfoides periféricos, na linfa do canal torácico e no sangue periférico.

Diferenciação entre os linfócitos $T$ e $B$. - Esta diferenciação tem sido mais inten- 


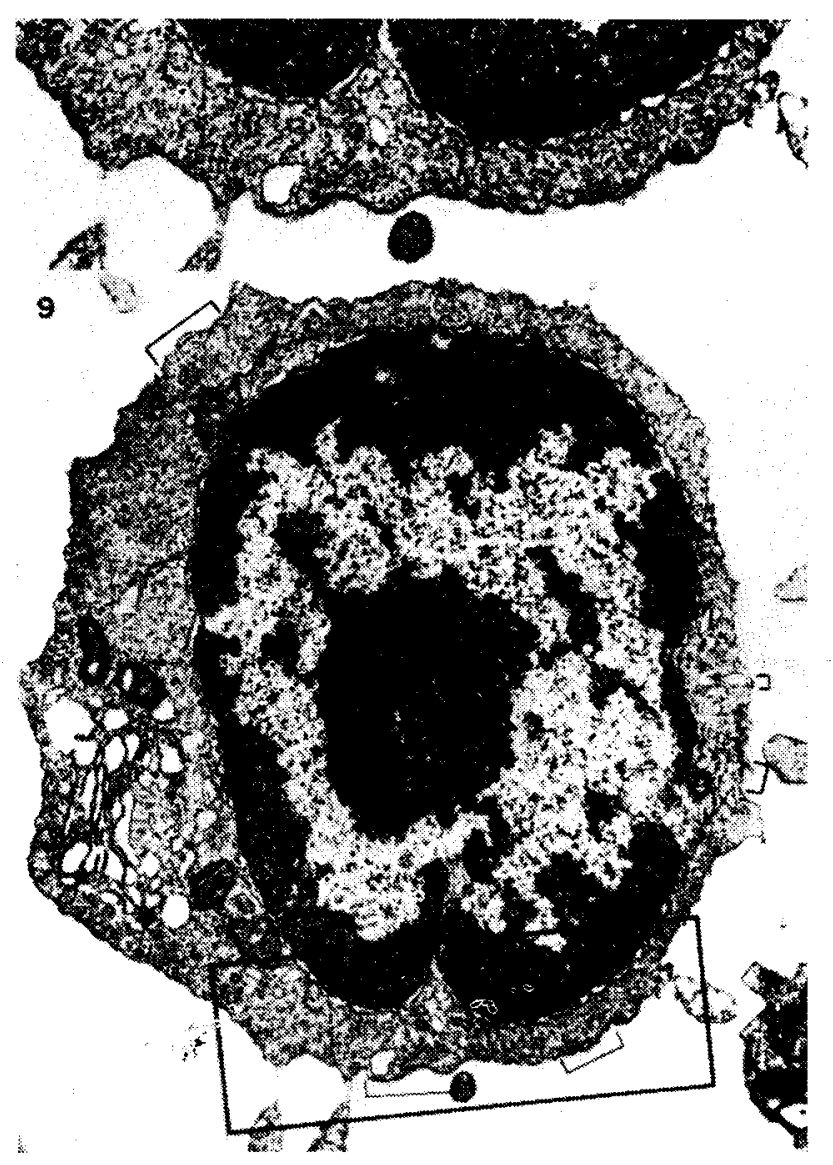

Fig. 10 Linfócito. Não se consegue distinguir os linfócitos $\mathrm{B}$ e $\mathrm{T}$ pelo aspecto morfológico.

samente estuciada no camundongo e se baseia, entre outras, nas seguintes propriedades: 1) somente os linfósitcs $T$ possuiriam o antígeno teta na sua membrana plasmática; 2) os linfócitos $\mathrm{B}$ conteriam antígenos não encontrados nos linfócitos T; 3) os linfócitos B seriam mais sensiveis à ação dos corticosteroides;; 4) somente os linfócitos B possuiriam receptores em sua membrana para complexos ligados a complemento. Como já foi dito, as células precursoras da medula óssea que migraram para o timo sa transformam $\mathrm{em}$ timscitos, quando adquirem os antígenos teta e TL. Com a diferenciação os ímócitos perdem o antigeno TL (conservando o antigeno teta) e migram para os órgãos lirifoides periféricos. A ciistribuição dos linfócitos $\mathrm{T}$ e $\mathrm{B}$, no camundongo, é a seguinte:

\begin{tabular}{l|r|r}
\hline & $\begin{array}{c}\text { Linfócito } \\
\%\end{array}$ & $\begin{array}{c}\text { Linfócito B } \\
\%\end{array}$ \\
\hline Timo ........... & 100 & 0 \\
Canal torácico ... & 85 & 15 \\
Sangue periférico . & 70 & 35 \\
Linfonodos ....... & 65 & 30 \\
Baço ........... & 35 & 56 \\
Peritôneo ........ & 35 & - \\
Placas de Fayer ... & 30 & - \\
Medula óssea ..... & 0 & 40 \\
\hline
\end{tabular}

Interação entre os linfócitos $T$ e $B$ e os macrófagos. - Uma estreita cooperação, funcional entre os linfócitos $\mathbf{T}$ e $\mathbf{B}$ está seguramente estabelecida em uma série de 
reaçōes imunológicas: 1) na formação de anticorpos; 2) na produção de anticorpo contra o hapteno e o "carreador"; 3) na reação enxerto-hospedeiro; 4) na tolerância imunológica. A produção de anticorpos pelos linfócitos $\mathbf{B}$ exige, na maioria das vezes, a colaboração cios linfócitos $T$. O contato do antígeno sensibilizador com os receptores da membrana plasmática leva os linfócitos $\mathrm{T}$ à diferenciação e elaboração de informação aos linfócitos B. Estes que também possuem receptores $\epsilon \mathrm{m}$ sua membrana se diferenciam em células produtoras de anticorpos. Os linfócitos $\mathrm{T}$ e $\mathbf{B}$ cooperam na formação de anticorpos contra antigenos contendo haptenos como determinante. O hapteno reage com os receptores dos linfócitos $\mathbf{B}$, enquanto a outrá parte da molécula, a porção "carreadora", reagirá com os receptores dos linfócitos $\mathbf{T}$. Todavia, nem todo antígeno requer a colaboração das células $\mathbf{T}$ para elaboração de anticorpos. Os antigenos com muitos de- terminantes iguais e repetidos (polissacarides, substâncias que se polimerizam) conseguem estimular diretamente os linfócitos B. As células $T$, graças à sua capacidade de recircular, podem captar o antígeno e concentrá-lo em zonas (dos linfonodos, baço) onde predominam os linfócitos $\mathbf{B}$.

Produção de linfocinas e dos fatores de transferência. - Quando os linfócitos $\mathrm{T}$, do animal ou do homem, adequadamente sensibilizados, são cultivados em presença do antigeno, aparecem, no sobrenadante da cultura, várias substâncias solúveis dotadas de atividade biológica de grande importância. Essas substâncias, que também pociem ser elaboradas por outros estímulos inespecificos (fitohemaglutinina, etc.) podem ser divididas em dois grupos: 1) das linfocinas; 2) dos fatores de transferência. O quadro seguinte condensa as principais linfocinas e suas propriedades biológicas.
Linfocina

Fator mitogênico (ou derepressor) dos linfócitos
Sistema biológico revelador da sua atividade

Induz a síntese de RNA, DNA pelos linfócitos, levando-os à transformação blástica.
Inđuz reação inflamatória retardada quando injetado por via intradérmica
Fator citotóxico ou citopático

Fator de inibição da migração

Fator agregador de macrófagos

Fator ativador dos macrófagos

Fator ativador dos linfonodos

Fator quimiotático
Citotoxicidade para células em condições adequadas, através da linfotoxina

Inibição da migração de macrófagos e neutrófilos, “in vitro"

Agregaçāo de macrófagos "in vitro" e "in vivo"

Aumenta a capacidade fagocitária dos macrófagos em cultura

Aumenta o tamanho dos linfonodos em injeçōes intralinfáticas

Quimiotaxia para macrófagos, neutrófilos, eosinófilos, linfócitos
Acelera a agregaçāo de plaquetas humanas em suspensão. 


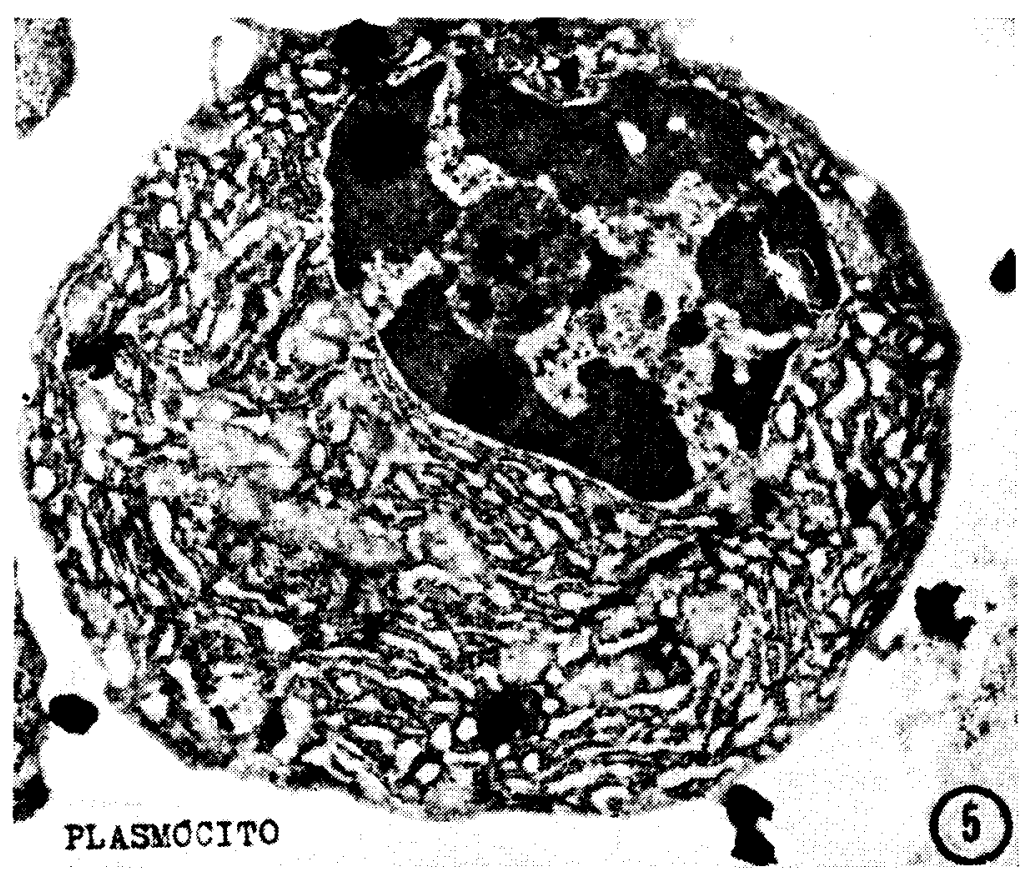

Fig. 11 Plasmócito. Fase final de evolução dos linfócitos B.

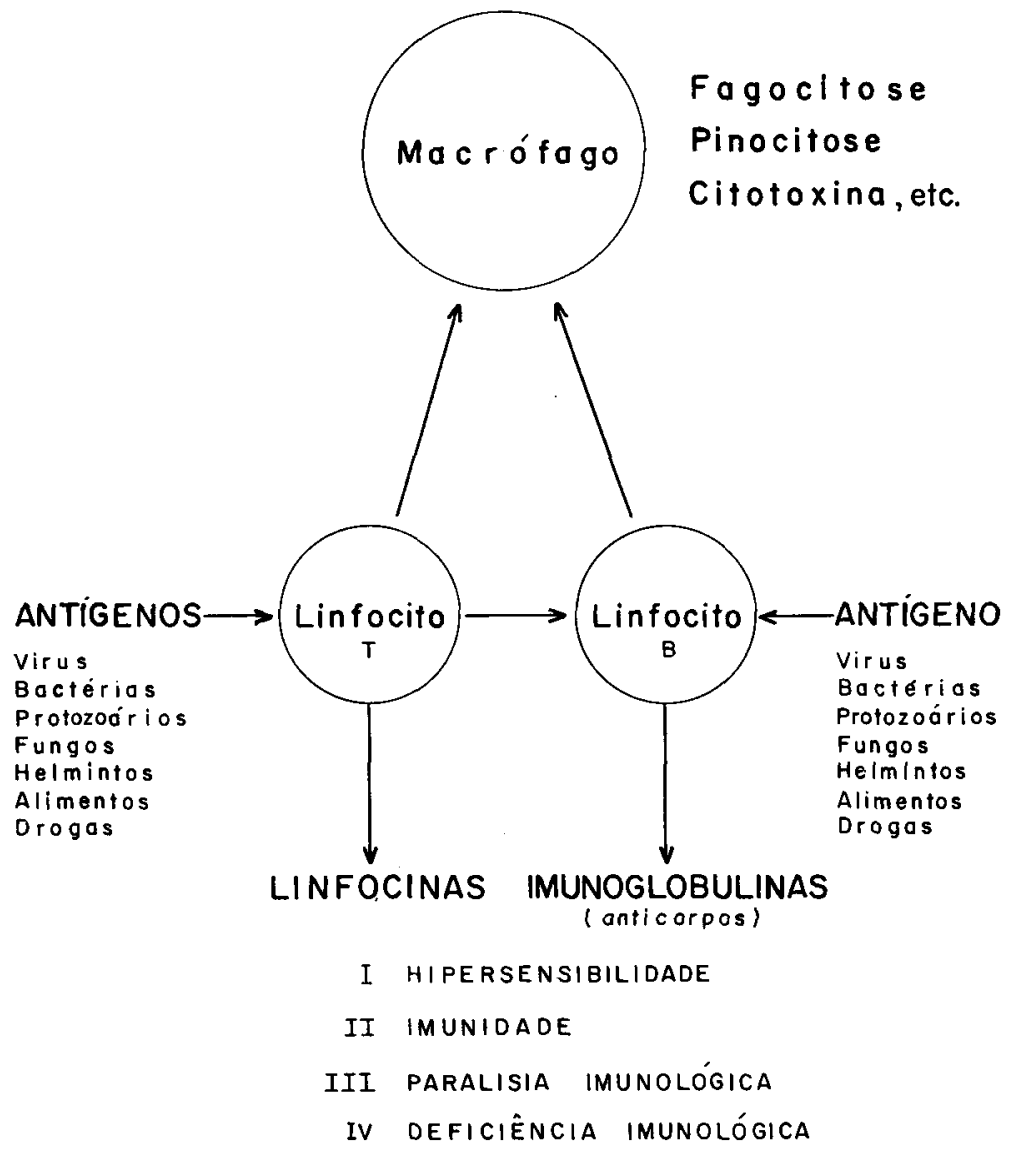

Fig. 12 As princlpais modalidades de resposta do sistema linforeticular em face de estímulos antigènicos 
As linfocinas funcionam como mediadores farmacológicos da hipersensibilidade e da imuniciade celular. Atuariam ampliando e regulando a resposta das células linfoides ao antígeno. Os fatores de transferência, também sem nenhum parentesco com as imunoglobulinas, existem preformados dentro das células linfoides (linfócitos $\mathrm{T}$ ), de individuos com elevado grau de hipersensibilidiade retardada, de onde podem ser facilmente extraídos. Estes fatores transferem a sensibilidade retardada de um indivíduo para o outro, quando injetados em doses adequadas. Consegue-se, também, transferir, "in vitro", a sensibiliciade de um linfócito para outro por meio desses fatores. Eles podem ser considerados como moléculas dotadas da capacidade de induzir as principais reações imunocelulares, enquanto que as linfocinas ampliam e regulam a extensão dessa resposta. Os fatores de transferência se obtem de linfócitos $\mathrm{T}$ sensibilizados, mesmo na ausência do antigeno; as linfocinas exigem a presença do antígeno sensibilizador e, aparentemente, da colaboração do macrófago. Cumpre lembrar que as linfocinas podem ser produzidas por células estimuladas inespecificamente.

Produção de imunoglobulinas (anticorpos). - Os anticorpos são globulinas que aparecem nos liquidos e tecidos de animal submetido a substâncias imunológicas. Uma das características principais dessas globulinas é a de se combinarem especificamente com os antígencs que presidiram à sua formação. São, por isso, chamadas imunoglobulinas. Os anticorpos são formados pelos linfócitos B, sobretudo pelos plasmócitos, que representam a etapa final de evolução desses linfócitos. Admite-se que o antigeno, se está em forma particulada (células, bactérias, etc.) antes de estimular a célula produtora de anticorpo, seja antes fagocitado ou "processado" pelos macrófagos. Como já vimos, os linfócitos T também auxiliam os linfócitos $\mathbf{B}$ na elaboração ảe anticorpo. Assim, em muitos casos, a formaçāo de anticorpo exige o concurso de pelo menos três células: macrófagos, linfócito $\mathrm{T}$ e linfócito $\mathrm{B}$.

Classes de imunoglobulinas. - Já se conhecem cinco classes de imunoglobulinas, designadas pelas siglas IgG, IgA, IgM, IgD, IgE. No homem existem ainda subclasses: IgG1, IgG2, IgG3, IgG4. Há pelo menos duas IgM denominadas IgM7S e IgM19S. A IgA é encontrada sob duas formas: $\operatorname{Ig}$ A e IgA-S. O componente $\mathbf{S}$ é chamado peça secretória, uma glicoproteina elaborada por células epiteliais (epitélio de revestimento). A IgA-S, chamada exócrina, encontra-se em teor elevado nas secreções (saliva, suco gástrico, colostro, etc.) e parece ser de grande importância na proteção das mucosas.

Algumas das propriedades das imunoglobulinas. - Essas propriedades podem ser condensadas no quadro seguinte.

\begin{tabular}{|c|c|c|c|c|c|}
\hline & $\operatorname{IgG}$ & $\operatorname{Ig} A$ & $\operatorname{Ig} M$ & $\operatorname{Ig} D$ & $\operatorname{Ig} E$ \\
\hline Mobilidade eletroforética & $\mathrm{y} 1, \mathrm{y} 2$ & y1 & y1 & y1 & y1 \\
\hline Peso molecular $\ldots \ldots \ldots$. & 160.000 & $\begin{array}{l}160.000 \\
390.000\end{array}$ & 900.000 & 160.000 & 200.000 \\
\hline $\begin{array}{c}\text { Teores normais no soro humano } \\
(\mathrm{mg} / 100 \mathrm{ml})\end{array}$ & 800 a 1600 & 140 a 420 & 50 a 200 & 0,3 a 30 & 0,01 a $(1,07$ \\
\hline Coeficiente de sedimentação ...... & $7 \mathrm{~S}$ & $7 \mathrm{~S} 11,4 \mathrm{~S}$ & $19 \mathrm{~S}$ & $7 \mathrm{~S}$ & $8 S$ \\
\hline Meia vida (dias) & 25 & 6 & 5 & - & - \\
\hline Especificidade genotipica & & & & & \\
\hline $\mathbf{G m} \ldots \ldots \ldots \ldots$ & + & 0 & $\mathbf{0}$ & - & - \\
\hline Inv & + & + & + & - & \\
\hline Valência & 2 & 2 & 5 & - & - \\
\hline Produção (g/dia) & 2,3 & 2,7 & 0,4 & - & - \\
\hline Transmissão pela placenta & + & 0 & 0 & - & 0 \\
\hline Fixação na pele... & ot & 0 & $\mathbf{0}$ & - & + \\
\hline Fix. complemento & + & 0 & + & - & $\mathbf{0}$ \\
\hline Combinação $c$ /fator reumatóide $\ldots$ & + & 0 & 0 & - & - \\
\hline Teor de carbohidratos $\ldots \ldots \ldots \ldots$ & 2,5 & 10,5 & 14,5 & - & - \\
\hline
\end{tabular}


Combinação antigeno-anticorpo. - $\mathrm{A}$ combinação antígeno-anticorpo se exterioriza por fenômenos físico-químicos e por manifestações biológicas, a saber: 1) formação de agregados moleculares; 2) precipitação e aglutinação; 3) fixação do complemento e citólise; 4) opsonização, imuncaderência e fagocitose; 5) liberação de substâncias farmacológicamente ativas sobre a microcirculação (histamina,serotonina, SRS-A, anafilatoxinas, bradicinina); 6) elaboração de linfocinas; 7) transformação blástica dos linfócitos; 8) alterações nos tecidos: inflamação simples, proliferação, degeneração, necrose, hemorragia, etc..

\section{A RESPOSTA IMUNOLÓGICA}

A resposta imunológica pode ser dividida em três compartimentos: aferente, central e eferente. A etapa aferente diz respeito à mensagem antigênica trazida ao sistema linfoide e à formação de anticorpo. A etapa central cuida da origem, natureza e função das células linfoides e da base genética da informação necessária para a síntese dos anticorpos. A etapa eferente estuda as alterações celulares que decorrem do encontro efetivo entre o antígeno e as células linfoides reatoras.

As reaçōes imunológicas podem ser classificadas em dois grandes grupos: 1) dependentes de substâncias elaboradas pelos linfócitos B (imunoglobulinas); 2) depencientes de substâncias elaboradas pelos linfócitos $\mathrm{T}$ (linfocinas $\mathrm{e}$ fatores de transferência). Dependem dos anticorpos a hipersensibilidade reagínica (atopia), o fenômeno de Arthus, a doença do soro, as reaçōes citotóxicas que envolvem o complemento, a eliminação de parasitas, a neutralização de toxinas, a imunidade humoral. Dependem das linfocinas e dos fatores cie transferência as formas de hipersensibilidade retardada (alergia bacteriana, alergia de contato, a rejeição de enxertos, a reação enxerto-hospedeiro), a destruição intravascular de parasitas, a imunidade celular. Tanto num grupo como no outro, as reações imunológicas são controladas por substâncias solúveỉ. elaboradas pelas células linfoides. Os macrófagos desempenham papel importantíssimo em praticamente toảa forma de reação imunológica, como já vimos.

\section{ESTADOS DE HIPERSENSIBILIDADE ESPECIFICA}

Os estados de hipersensibilidade específica resultam de uma hiperplasia do sistema linforeticular com aumento da atividade funcional das suas células, ocasionada pela introdução no organismo de substâncias imunogênicas em condiçōes adequadas. O processo hiperplástico poderá ser dominante em alguns dos setores desse sistema, ou poderá estender-se a todos eles. Quando dominante no setor cias células formadoras de anticorpo (linfócitos B), ocorrerão as formas de hipersensibilidade de resposta imediata (anafilaxia, alergia reagínica, fenômeno de Arthus, doença do soro) ; quando dominante no setor dos linfócitos $T$, instalar-se-ão formas de hipersensibilidade do tipo retardado (alergia bacteriana, alergia de contato, rejeição de enxerto, reação enxerto-hospedeiro) . Quando a hiperplasia se estende aos dois setores de células ocorrerão estados de hipersensibilidacie mistos, imediatos e retardados.

As linfocinas na hipersensibilidade retardada. - Os principais testes de investigação da hipersensibilidade retardada, em nível celular, são as seguintes: 1) transformação blástica dos linfócitos $\mathrm{em}$ presença do antigeno; 2) inibição da migração cios macrófagos; 3) testes de citotoxicidade dos linfócitos. As linfocinas seriam os mediadores principais dessas reações celulares. Em qualquer situação as linfocinas e os fatores de transferência podem ser distinguidos dos anticorpos e dos produtos da interação antígeno-anticorpo. Todavia, muitas situações clínicas (hipersensibilidade mista, imunidade humoral e celular) dependem da ação combinada das linfocinas, dos fatores de transferência e das imunoglobulinas. O significado clínico das linfocinas poderá ter as seguintes expressões na resposta imunológica. 


\section{Reações inflamatórias:}

Hipersensibilidade retardada

Formação de granuloma

Rejeiçāo de transplantes

Reação enxerto-hospedeiro

Reações de vigilância:

Restrição no crescimento de tumores, parasitas

Destruição de parasitas

Ativação de macrófagos

\section{Reações adjuvantes:}

Formação de anticorpo

Promoção da resposta auto-imune.

\section{IMUNIDADE HUMORAL E CELULAR}

Para que o parasita que venceu os mecanismos inespecíficos de defesa crie um estado cie imunidade, de maior resistência ao agente invasor, é indispensável que esse agente, ou seus antígenos, entre na intimidade do sistema linforeticular. A resposta desse sistema se exterioriza de duas formas que, em geral, se desenvolvem paralelas: 1) imunidade humoral; 2) imunidade celular.

A principal característica da imunidade humoral é o aparecimento no sangue de imunoglobulinas (anticorpos) elaboradas pelos linfócitos B (plasmócitos) e que entram em combinação específica com o parasita ou seus antígenos solúveis. Os anticorpos auxiliam a tarefa a ser executada pelos macrófagos, a fagocitose, de várias maneiras: 1) neutralizando as exotoxinas; 2) atuando como opsoninas ou anticorpos citofilicos e que possibilitam a aderência dos parasitas à superfície dos macrófagos (imunoaderência); 3) funcionando como agente citotóxico para o parasita, em presença do complemento.

A imunidade celular se caracteriza pelo aparecimento de células linfoides (linfócitos $T$ ) especificamente sensibilizados aos antígenos do parasita. Quando em contato com o parasita eles se transformam em células blásticas (células pironinófilas) com a capacidade de elaborarem as linfocinas, os fatores de transferência, o interferon, como já fci descrito. As linfocinas exer-
Fatores: inflamatório, citotoxina, quimiotático, mitogênico, inibidor da migração de macrófagos, aglutinador de macrófagos.

Fatores: citotóxico, ativador de macrófagos

Fatores: ativador do linfonodo, mitogênico, ativador de macrófagos.

cem papel importante na atividade dos macrófagos, aumentando sua capacidade de fagocitose, tornando-os "macrófagos ativados", levando-os a se organizarem em granulomas, etc. Quando os linfócitos $\mathbf{T}$ deixam de fornecer essa ajuda aos macrófagos, como acontece em caráter temporário na fase aguda de certas viroses (sarampo, rubeola, mononucleose infecciosa, etc.), ou em caráter duradouro, em algumas doenças com deficiência imunológica (calazar, lepra iepromatosa, blastomicose, condiçōes neoplásicas, etc.) a imunidade celular fica grandemente prejudicada, ora em caráter específico, ou em caráter inespecífico, tornando precária a situação do hospedeiro. Embora se desconheça o mecanismo íntimo pelos quais os linfócitos timodependentes, sensibilizados, executam essa funçāo, se somente através das linfocinas e dos fatores de transferência, o chamado eixo "macrófago-linfócito", timo-dependente, constitui a base atual da imunidade celular.

A imunidade celular poderá ser encarada sob dois aspectos tendo em mente seu significado clínico: 1) o que diz respeito ao aumento das propriedades parasiticidas cios macrófagos; 2) o que se refere ao papel dos macrófagos na imunidade anti-célula neoplásica.

De há muito se sabe que os macrófagos de animais infectados com o $M$. tuberculosis adouirem maior capacidade de inibir o crescimento dos parasitas intracelulares facultativos. Estudos mais recentes, usando a 
L. monocytogenes, em camundongos, revelaram que a maior resistência dos animais infectacios nāo tem caráter estritamente específico. O estímulo ao sistema linforeticular, independentemente do agente agressor (BCG, Salmonella, Brucella, Listeria, etc.), em elevado grau, se exterioriza por efeitos inespecíficos, que se generalizam envolvendo os macrófagos do fígado, baço, pulmões, peritôneo, pleura, etc.

Uma outra questão muito importante no setor da imunidade celular é o que diz respeito à viabilidade do parasita em causa. Em geral, só os agentes viáveis, isto é, aqueles que conseguem sobreviver nos tecidos, não importanảo de que maneira se opere essa sobrevivência, serão capazes de criar imunidade celular duradoura. Raramente se consegue esse estado de imunidade com bactérias mortas, ou com seus antígenos. A imunidade celular duradoura parece exigir uma estimulação antigênica persistente com o que se conseguiria uma contínua ativação dos macrófagos. Ademais, pensam alguns pesquisadores, essa estimulação precisa atingir também as células da medula óssea precursora dos macrófagos.

\section{TOLERANCIA OU PARALISIA IMUNOLÓGICA}

Estado em que não há resposta, em caráter especifico, das células do sistema linforeticular, imunocompetentes, quando estimuladas pelo antígeno, em condições adequadas. Pode ser criado por diferentes métodos, em condições experimentais: 1) inoculação do antígeno em animais recémnascidos; 2) inoculação do antígeno em doses elevadas ou em doses muito peçuenas; 3) injeçāo do antígeno (proteínas) livre de agregados, isto é, submetidas a alta centrifugação; 4) animais submeticios à radioterapia; 5) com drogas imunosupressoras durante a estimulação antigênica; 6) com soros anti-linfócitos timo-dependentes, heterólogos, etc. A tolerância imunológica, uma vez estabelecida, pode durar por longo período, ou pode terminar espontaneamente com o auxílio de vários recursos técnicos. Fermanece obscuro o mecanismo íntimo dos estados de tolerância imunológica. Sabe-se, no entanto, que eles podem ocorrer tanto no setor dos linfócitos $T$, como cios linfócitos $\mathbf{B}$, ou de ambos simul- tâneamente, e que podem ocorrer no decurso de qualquer tipo de parasitismo.

\section{ESTADOS DE DEFICIÊNCIA IMUNOLÓGICA}

Os estados de deficiência imunológica podem ocorrer no setor dos linfócitos $T$, dos linfócitos B ou, simultâneamente, nos dois setores. As agamaglobulinemias, ou hipogamaglobulinemias, constituem os principais achados imunológicos nas condições com deficiência imunológica dos linfócitos B. Os estacios com deficiência imunológica no setor dos linfócitos $T$ decorreriam de uma hipoprodução de linfocinas, quer seletiva, quer global. Os mediadores dos linfócitos $\mathrm{T}$ e $\mathrm{B}$, as linfocinas e as imunoglobulinas, teriam, assim, enorme importância não somente nos estados de hipersensibilidade e de imunidade, mas também, nos estacios de deficiência imunológica. No quadro seguinte estão as principais condiçōes em que se demonstra facilmente um estado de deficiência imunológica.

\section{I) Deficiências imunológicas primárias:}

1) Celular (aplasia tímica, etc.)

2) Humoral (hipogamaglobulinemia ligado ao sexo)

3) Celular e humoral (autosômica)

\section{II) Parasitismo intracelular crônico:}
1) Candidiase muco-cutâneo
2) Leishmaniose visceral
3) Leishmaniose cutânea difusa
4) Lepra lepromatosa
5) Blastomicose

III) Neoplasias:
1) Doença de Hodgkin
2) Leucemia linfática crônica
3) Carcinomas avançados

IV) Doenças granulomatosas crônica:
1) Sarcoidose
2) Doença de Crohn
3) Cirrose biliar primária 
V) Afecçóes viróticas ativas:
1) Sarampo
2) Rubeola
3) Mononucleose infecciosa

VI) Uso de imunosuprescores.

Nas sindromes de deficiência imunológica dos linfócitos $B$, em que existe baixa do teor dos anticorpos, global ou seletiva, as repercussóes sobre a imunidade humoral (baixa da resistência aos agentes bac- terianos, viróticos, etc.) dependem de vários fatores: época de aparecimento, duração, características genéticas, teores de imunoglobulinas do soro, etc. Na sindrome com deficiência dos linfócitos $\mathrm{T}$ ocorrem, entre outras, as seguintes manifestaçōes: linfocitopenia, plasmacitose, hipo ou hipergamaglobulina, amiloidose, teste de Coombs positivo, incapacidade no controle da homeostase imunológica, mutaçōes scmáticas, hiperplasia de células reticulares, infecções viróticas repetidas, fenômenos de autoagressão, processos neoplásicos.

\section{REFERẼNCIAS BIBLIOGRÁFICAS}

1. ABDOU, N. I. \& RICHTER, M. - The role of bone marrow in the imune response. Adv. Imunol. 12: 202, 1970.

2. AUSTEN, K. F. \& BECKER, E. L. Biochemistry of the acute allergic reactions. Blackwell, Oxford, 1972.

3. BROWN, I. N. - Immunological aspects of malaria. Ad. Immunol. 11: 268,1969 .

4. BRYCESON, A. D. M.; BRAY, R. S.; WOLSTENCROFT, $R$. A. \& DUMMONDE, D. C. - Immunity in cutaneous leishmaniasis of the guinea pig. Clin. Exp. Immunol. 7: 301, 1970.

5. COHEN, J. J. \& CLAMAN, H. N. The thymus - marrow immunocompetence, J. Exp. Med. 133: 1026, 1971.

6. COHN, Z. A. - The structure and function of monocytes and macrophages Adv. Immunol. 8: 164, 1965.

7. DAVID, J. R. - - Mediators produced by sensitized lymphocytes Fed. Proc. 30: $1730,1971$.

8. DUMMONDE, D. C. \& MAINI, R. N. - The clinical significance of mediators of cellular immunity. Clin. Allergy 1: $123,1971$.

9. FIORE-DONATI, L. \& HANNA, M. G Jr. - Lymphatic tissue and germinal centers in immune response. Plenum Press, New York, 1969.

10. FULTON, J. D. - Acquired immunity: protozoal infections. in Modern Trend in Immunology. Ed. Cruickshank, R. Butterworths, Londob. 1963.

11. HEYNEMAN, D. - Immunology to leishmaniasis. Bull. Wld. Hlth. Org. 44: 499,1971 .
12. LAWRENCE, H. S. - Cellular and humoral aspects of hypersensitivity states. Hoeber. New York, 1959.

13. MACKANESS, G. B. - Resistance to intramuscular infections. J. Infect. Dis. 123: 439, 1971.

14. MACKANESS, G. B. \& BLANDEN, R. V. - Cellular immunity. Progr. Allergy 11: 36, 1967.

15. MUDD, S. - Infectious agents and host reactions. S. W. Saunders Co.. Philadelphia, 1970.

16. NELSON, D. S. - Macrophages and immunity. North Holland Publishing Co., Amsterdan, 1969.

17. NOSSAL, G. J. V. \& ADA, G. L. Antigens, lymphoid cells and the immune response. Academic Press. New York, 1971.

18. PEARSAL, N. N. \& WEISER, R. S - The macrophages. Lea and Febiger. Philadelphia, 1970.

19. PEARLMANN, P. \& HOLM, G. - Cytotoxic effects of lymphoid cells in vitro. Adv. Immunol., 11: 117, 1969.

20. RAFF, M. C. - T and B lymphocytes in mice studied by using antisera against surface antigenic markers. Amer. J. Path. 65: 467, 1971.

21. SMITH, R. \& LANDY, M. - Immune surveillance. Academic Press, New York. 1970.

22. SISKIND. G. W. \& BENACERRAF, B. - Cell selection by antigen in the immune response. Adv. Immunol. 10. 1,1969 . 
23. TAIMAGE, D. W. ; RADOVICH, J. \& HEMMINGGSEN, $\mathrm{H}$. - Cell interaction in antibody synthesis. Adv. Immunol. 12: 271, 1970.

24. TAYLOR, A. E. R. - Immunity to parasites. Blackell. Oxford. 1968.

25. TURK, J. L. - Delayed hypersensitivity. North Holland Publishing Co. Amsterdam, 1967.

26. VAN FURTH, R. - Mononuclear phagocytosis. Blackwell. Oxford.
27. WEIGLE, W. O. - N a tu ra 1 and acquired immunologic unresponsiveness. The World Publishing Co. New York, 1967.

28. WEIR, D. M. - Handbook of experimental immunity. Blackwell. Oxford, 1968 .

29. WEISSMAN, G. \& DUKOR, P. - The role of lysosomes in immune responses. Adv. Immunol. 12: 283, 1970. 